\title{
ANALISIS EFEKTIVITAS PENJAMINAN KREDIT USAHA RAKYAT PADA PERUM JAMKRINDO KANTOR CABANG MANADO
}

\author{
Timoty Erlan Kenny Umboh ${ }^{1}$, Grace B. Nangoi ${ }^{2}$, Heince R.N Wokas ${ }^{3}$ \\ 1,2,3 Jurusan Akuntansi, Fakultas Ekonomi dan Bisnis, Universitas Sam Ratulangi, Jl. Kampus Bahu, Manado, \\ 95115, Indonesia \\ E-mail : malalayangers95@gmail.com
}

\begin{abstract}
Improving the performance of UMKM is faced by various obstacles and challenges on the competition. Lack of capital owned by UMKM entrepreneurs is a challenges at this time. UMKM entrepreneurs are difficult to obtain loan capital because they don't have enough assets to complete the requirements of bank loans. To solve this problem, the government issued a policy credit program for UMKM with loans named People Business Credit Programs. This study aims to observe the Effectiveness of Credit Guarantee Effort of Public Enterprises at General Company Credit Guarantee Indonesia (Jamkrindo) Manado Branch Office. This research was conducted in Manado City with data taken from Public Credit Guarantee Company of Indonesia (Jamkrindo) Manado Branch Office using Qualitative research method and research method used by interview. The results of this study show that the Effectiveness Credit Guarantee Effectiveness Criteria in Manado has been running Effectively with the Effectiveness criteria in 2015 is $94.02 \%$ then in 2016 reached $95.87 \%$ and in 2017 reached $93.93 \%$.
\end{abstract}

Keywords : Effectiveness, Credit Guarantee, People Business Credits, UMKM

\section{PENDAHULUAN}

Pertumbuhan dan pemerataan ekonomi merupakan indikator dalam proses pembangunan sebuah Negara, terlebih lagi bagi Negara-negara yang sedang berkembang dimana pembangunan diarahkan untuk mencapai tingkat kemakmuran bagi rakyatnya. Di Indonesia, tujuan tersebut tercantum dalam pembukaan Undang-Undang Dasar 1945 yaitu untuk "Memajukan kesejahteraan umum".

Tujuan ini memiliki maksud bahwa kesejahteraan masyarakat Indonesia adalah prioritas terpenting dalam proses pembangunan Indonesia. Bertahannya usaha mikro,kecil maupun menengah (UMKM) dalam menghadapi krisis dan kondisi perekonomian yang tidak stabil telah menunjukkan betapa pentingnya sektor ini dalam hal membantu perekonomian nasional. Meskipun berskala kecil, namun jenis usaha ini memiliki kontribusi yang tidak sedikit terhadap perekonomian nasional. (Aditya, 2014:3)

Menurut Evi (2016:6) pada saat ini pengembangan UMKM masih dilanda berbagai hambatan dan tantangan dalam menghadapi dunia usaha yang semakin ketat. Namun demikian dengan berbagai keterbatasan yang ada, UMKM masih diharapkan mampu menjadi andalan perekonomian Indonesia. Usaha Mikro Kecil Menengah diharapkan dapat berperan sebagai salah satu sumber penting dalam meningkatan sumber pendapatan dan memperluas kesempatan kerja bagi masyarakat. Di Indonesia UMKM telah menjadi bagian penting dari sistem perekonomian di Indonesia. Hal ini dikarenakan UMKM merupakan unit-unit usaha yang lebih banyak jumlahnya dibandingkan usaha industri berskala besar dan memiliki keunggulan dalam menyerap tenaga kerja lebih banyak dan juga mampu mempercepat proses pemerataan sebagai bagian dari pembangunan. Peningkatan kinerja UMKM dilanda berbagai hambatan dan tantangan dalam menghadapi persaingan. Kurangnya modal yang dimiliki pengusaha UMKM merupakan tantangan yang dihadapi saat ini. 
Peran perbankan dalam pembangunan ekonomi adalah mengalirkan dana bagi kegiatan ekonomi yaitu salah satunya dalam bentuk perkreditan bagi masyarakat perseorangan atau badan usaha. Kredit tersebut mempunyai suatu kedudukan yang strategis dimana sebagai salah satu sumber uang yang diperlukan dalam membiayai kegiatan usaha yang dapat dititikberatkan sebagai salah satu kunci kehidupan bagi setiap manusia. Fasilitas kredit yang diberikan oleh bank merupakan aset terbesar bagi bank. Dalam hal kegiatan bank memberikan fasilitas kredit, resiko kerugian sebagian besar bersumber pada kegiatan tersebut, sehingga bila tidak dikelola dengan baik dan disertai pengawasan yang memadai akan mengancam kelangsungan hidup bank tersebut. (Nurul, 2010:17)

Peranan industri perbankan dalam rangka penunjang perekonomian dapat dilakukan dengan cara menghimpun dan menyalurkan dana kepada masyarakat dengan sumber perolehan dana bank berasal dari simpanan atau tabungan masyarakat yang dimaksukkan dalam bank berupa giro, deposito,tabungan, dan sebagainya yang kemudian akan di salurkan kembali kepada masyarakat yang membutuhkan dana terutama pada dunia usaha dalam bentuk pinjaman atau kredit kepada nasabahnya. (Samosir, 2016:10)

Masalah mengenai modal dan kredit tidaklah terlepas dari pembicaraan mengenai bank dan perusahaan penjaminan, sebab bank diperlukan sebagai lembaga penyalur pembayaran dan peredaran uang dan perusahaan penjaminan sebagai pemodal atau pihak ketiga sebagai penjamin nasabah akan melunasi kredit yang diajukan. Profitabilitas untuk perusahaan manapun mengharuskan pengembalian melebihi biaya modal (Sagner, 2016:2)

Efektivitas pemberian kredit adalah tercapainya realisasi pemberian kredit berdasarkan target yang telah ditetapkan oleh bank (Putu Clarita, 2013:1). Di dalam hal pengkreditan pastilah ada suatu masalah, munculnya kredit bermasalah termasuk di dalamnya kredit macet, pada dasarnya tidak terjadi secara tiba-tiba melainkan melalui suatu proses. Pinjaman tidak ditanggapi dengan serius karena sistem pengelolaan peminjaman kurang baik (Damaris, 2015:3). Terjadinya kredit macet dapat disebabkan baik oleh pihak Bank maupun Nasabah. Tujuan penelitian yang ingin dicapai dalam penelitian ini adalah untuk menganalisis Efektivitas Program Kredit Usaha Rakyat di Perum Jamkrindo Kantor Cabang Manado apakah sudah berada pada kriteria efektif.

\section{TINJAUAN PUSTAKA}

\subsection{Akuntansi Manajemen}

Akuntansi manajemen adalah penerapan konsep dan metode yang tepat dalam mengelolah data ekonomi masa lalu dan membuat proyeksi masa depan suatu usaha untuk membantu manajemen dalam penyusunan rencana tujuan perusahaan dan pengambilan keputusan untuk mencapai tujuan tersebut.

\subsection{Pengertian Kredit}

Dalam arti luas kredit diartikan sebagai sebagai kepercayaan. Begitu pula dengan bahasa latin kredit berarti "credere" yang artinya percaya. Maksud dari percaya bagi si pemberi kredit adalah ia percaya kepada si penerima kredit bahwa kredit yang disalurkannya pasti akan dikembalikan sesuai perjanjian. Sedangkan bagi si penerima kredit merupakan penerimaan kepercayaan sehingga mempunyai kewajiban untuk membayar sesuai dengan jangka waktu. (Kasmir, 2012:103)

\subsection{Efektivitas Penjaminan Kredit}

Ulum (2009:26) menyatakan efektivitas merupakan hubungan antara keluaran dengan tujuan atau sasaran yang harus dicapai. Kegiatan operasional dikatakan efektif apabila proses kegiatan mencapai tujuan dan sasaran akhir kebijakan (spending wisely). Indikator efektivitas menggambarkan jangkauan akibat dan dampak (outcome) dari keluaran atau output program dalam mencapai tujuan program. Semakin besar kontribusi output pada pencapaian tujuan, maka semakin efektif organisasi, program, atau kegiatan. 
Menurut Julita (2013:4) efektivitas adalah kesuksesan atau kegagalan antara keluaran dengan tujuan atau sasaran yang harus dicapai. Untuk menghitung tingkat efektivitas dapat digunakan rumus sebagai berikut:

$$
\text { Efektifitas }=\frac{\text { Ouput aktual }}{\text { Output target }} \times 100 \%
$$

Artinya, pemberian kredit dikatakan efektif apabila jumlah output aktual lebih besar atau sama dengan output target.

\subsection{Kredit Usaha Rakyat}

Menurut Peraturan Menteri Keuangan Nomor 135/PMK.05/2008 Kredit Usaha Rakyat adalah pemberian modal kerja dan investasi yang diberikan kepada UMKM-K dengan fasilitas penjaminan untuk usaha produktif. Pemberian kredit merupakan pemberian kepercayaan, yang berarti bank akan memberikan kredit jika bank yakin bahwa calon debitur akan mengembalikan pinjaman sesuai dengan kesepakatan antara kedua belah pihak. Bank akan melakukan proses analisis kredit terlebih dahulu sebelum calon debitur dikatakan layak untuk menerima fasilitas kredit. Kelayakan kredit dapat dinilai dengan menggunakan beberapa metode yaitu analisis kredit 6C, analisis laporan keuangan, dan analisis perhitungan kebutuhan kredit modal kerja.

\subsection{Pinjaman Kredit}

Ulum (2009:26) menyatakan efektivitas merupakan hubungan antara keluaran dengan tujuan atau sasaran yang harus dicapai. Kegiatan operasional dikatakan efektif apabila proses kegiatan mencapai tujuan dan sasaran akhir kebijakan (spending wisely). Indikator efektivitas menggambarkan jangkauan akibat dan dampak (outcome) dari keluaran atau output program dalam mencapai tujuan program. Semakin besar kontribusi output pada pencapaian tujuan, maka semakin efektif organisasi, program, atau kegiatan.

\section{METODE PENELITIAN}

\subsection{Jenis Penelitian}

Berdasarkan tujuannya, penelitian ini termasuk dalam peneitian deskriptif (descriptive research). Menurut Arikanto (2013:174) metode deskriptif adalah penelitan yang dimaksudkan untuk menyelidiki keadaan, kondisi atau hal lain-lain yang sudah disebutkan yang hasilnya dipaparkan dalam laporan penelitian

\subsection{Tempat dan Waktu Penelitian}

Penelitian ini dilakukan di Perum Jamkrindo Kantor Cabang Manado Sulawesi Utara dalam bentuk wawancara yang sudah disiapkan sebelumnya sebelum penelitian dilakukan. Waktu penelitian adalah bulan Oktober sampai November 2017.

\subsection{Prosedur Penelitian}

1. Mengajukan permohonan penelitian

2. Disposisi Pimpinan

3. Pengumpulan data

4. Analisis data Penelitian dan Pembahasan

5. Menarik Kesimpulan

\subsection{Sumber Data}

Sumber data yang digunakan peneliti dalam penelitian ini adalah data primer, yaitu memperoleh data dari pihak Perum Jamkrindo Kantor Cabang Manado melalui wawancara.

\subsection{Metode Analisis}

Metode yang digunakan untuk menganalisis data adalah metode deskriptif yaitu metode yang digunakan untuk menggambarkan atau menganalisis suatu hasil penelitian tetapi tidak digunakan untuk membuat kesimpulan yang lebih luas (Sugiyono 2011:21). 
Perhitungan efektivitas pemberian kredit menggunakan rumus berikut :

$$
\text { Efektifitas }=\frac{\text { Ouput aktual }}{\text { Output target }} \times 100 \%
$$

Sesuai keputusan Menteri Dalam Negeri No. 690.900-327 tahun 1996 tentang kriteria penilaian dan kinerja keuangan dapat diketahui efektif atau tidak dengan memenuhi kriteria sebagai berikut.

Pengukuran Efektivitas

\begin{tabular}{|c|c|}
\hline Efektivitas & Kriteria \\
\hline$>100 \%$ & Sangat Efektif \\
\hline $90-100 \%$ & Efektif \\
\hline $80-90 \%$ & Cukup Efektif \\
\hline $60-80 \%$ & Kurang Efektif \\
\hline$<60 \%$ & Tidak Efektif \\
\hline
\end{tabular}

\section{HASIL PENELITIAN DAN PEMBAHASAN}

\subsection{Hasil Penelitian}

Berikut adalah pengajuan penjaminan kredit usaha rakyat dari bank kepada Perusahaan Umum Jamkrindo yang di terima :

Rekapitulasi Penerimaan Sertifikat Penjaminan (2015)

\begin{tabular}{|l|l|c|c|c|c|}
\hline No & \multicolumn{1}{|c|}{$\begin{array}{c}\text { Penerima } \\
\text { Jaminan }\end{array}$} & $\begin{array}{c}\text { Wilayah } \\
\text { Kerja }\end{array}$ & $\begin{array}{c}\text { Permohonan } \\
\text { Penjaminan } \\
\text { Yang Masuk }\end{array}$ & Diterima & Ditolak \\
\hline 1 & Bank Mandiri & Manado & 20 & 16 & 4 \\
\hline 2 & $\begin{array}{l}\text { Bank Negara } \\
\text { Indonesia }\end{array}$ & Manado & 7 & 4 & 3 \\
\hline 3 & $\begin{array}{l}\text { Bank Rakyat } \\
\text { Indonesia }\end{array}$ & Manado & 224 & 216 & 8 \\
\hline & Jumlah & & 251 & 236 & 15 \\
\hline
\end{tabular}

Sumber : Jaminan Kredit Indonesia Kantor Wilayah Makassar

1. Bank Mandiri meneruskan berkas pengajuan KUR kepada Perum Jamkrindo Sebanyak 20 Pengajuan dengan 16 Sertifikat Penjaminan (SP) diterbitkan dan 4 Nasabah ditolak

2. Bank Negara Indonesia meneruskan berkas Pengajuan KUR kepada Perum Jamkrindo Sebanyak 7 Pengajuan dengan 4 Sertifikat Penjaminan (SP) diterbitkan dan 4 Pengajuan Nasabah ditolak

3. Bank Rakyat Indonesia meneruskan berkas Pengajuan KUR kepada Perum Jamkrindo Sebanyak 224 Pengajuan dengan 216 Sertifikat Penjaminan (SP) diterbitkan dan 8 Nasabah ditolak

Dilihat dari keseluruhan Tabel maka Jaminan Kredit Indonesia Wilayah Manado menerima 251 Permohonan Penjaminan Yang Masuk dengan 236 yang diterima dan 15 yang ditolak. 
Rekapitulasi Penerimaan Sertifikat Penjaminan (2016)

\begin{tabular}{|l|l|c|c|c|c|}
\hline No & \multicolumn{1}{|c|}{$\begin{array}{c}\text { Penerima } \\
\text { Jaminan }\end{array}$} & $\begin{array}{c}\text { Wilayah } \\
\text { Kerja }\end{array}$ & $\begin{array}{c}\text { Permohonan } \\
\text { Penjaminan Yang } \\
\text { Masuk }\end{array}$ & Diterima & Ditolak \\
\hline 1 & Bank Mandiri & Manado & 135 & 125 & 10 \\
\hline 2 & $\begin{array}{l}\text { Bank Negara } \\
\text { Indonesia }\end{array}$ & Manado & 122 & 118 & 4 \\
\hline 3 & $\begin{array}{l}\text { Bank Rakyat } \\
\text { Indonesia }\end{array}$ & Manado & 494 & 477 & 17 \\
\hline & Jumlah & & 751 & 720 & 31 \\
\hline
\end{tabular}

Sumber : Jaminan Kredit Indonesia Kantor Wilayah Makassar

1. Bank Mandiri meneruskan berkas Pengajuan KUR kepada Perum Jamkrindo Sebanyak 135 Pengajuan dengan 125 Sertifikat Penjaminan (SP) diterbitkan dan 10 Nasabah ditolak

2. Bank Negara Indonesia meneruskan berkas Pengajuan KUR kepada Perum Jamkrindo sebanyak 122 Pengajuan dengan 118 Sertifikat Penjaminan (SP) Diterbitkan dan 4 Nasabah ditolak

3. Bank Rakyat Indonesia meneruskan berkas Pengajuan KUR kepada Jamkrindo sebanyak 494 Pengajuan dengan 477 Sertifikat Penjaminan (SP) diterbitkan dan 17 Nasabah ditolak

Dilihat dari keseluruhan Tabel maka Jaminan Kredit Indonesia Wilayah Manado menerima 751 Permohonan Penjaminan Yang Masuk dengan 720 yang diterima dan 31 yang ditolak.

Rekapitulasi Penerimaan Sertifikat Penjaminan (2017)

\begin{tabular}{|l|l|c|c|c|c|}
\hline No & \multicolumn{1}{|c|}{$\begin{array}{c}\text { Penerima } \\
\text { Jaminan }\end{array}$} & $\begin{array}{c}\text { Wilayah } \\
\text { Kerja }\end{array}$ & $\begin{array}{c}\text { Permohonan } \\
\text { Penjaminan Yang } \\
\text { Masuk }\end{array}$ & Diterima & Ditolak \\
\hline 1 & Bank Mandiri & Manado & 47 & 45 & 2 \\
\hline 2 & $\begin{array}{l}\text { Bank Negara } \\
\text { Indonesia }\end{array}$ & Manado & 19 & 16 & 3 \\
\hline 3 & $\begin{array}{l}\text { Bank Rakyat } \\
\text { Indonesia }\end{array}$ & Manado & 429 & 404 & 25 \\
\hline & Jumlah & & 495 & 465 & 30 \\
\hline
\end{tabular}

Sumber : Jaminan Kredit Indonesia Kantor Wilayah Makassar

1. Bank Mandiri meneruskan berkas Pengajuan KUR kepada Perum Jamkrindo Sebanyak 47 Pengajuan dengan 45 Sertifikat Penjaminan (SP) diterbitkan dan 2 Nasabah ditolak

2. Bank Negara Indonesia meneruskan berkas Pengajuan KUR kepada Perum Jamkrindo Sebanyak 19 Pengajuan dengan 16 Sertifikat Penjaminan (SP) diterbitkan dan 3 Nasabah ditolak

3. Bank Rakyat Indonesia meneruskan berkas Pengajuan KUR kepada Perum Jamkrindo Sebanyak 429 Pengajuan dengan 404 Sertifikat Penjaminan (SP) diterbitkan dan 25 Nasabah ditolak

Dilihat dari keseluruhan Tabel maka Jaminan Kredit Indonesia Wilayah Manado menerima 495 Permohonan Penjaminan Yang Masuk dengan 465 yang diterima dan 30 yang ditolak. 


\subsection{Pembahasan}

\subsubsection{Efektivitas Penjaminan Kredit}

Perhitungan Efektivitas Penjaminan Kredit Usaha Rakyat

\begin{tabular}{|l|c|c|c|c|c|c|c|c|c|}
\hline Keterangan & \multicolumn{3}{|c|}{2015} & \multicolumn{3}{c|}{2016} & \multicolumn{3}{c|}{2017} \\
\cline { 2 - 9 } & Target & Aktual & $\begin{array}{c}\text { Efektivi } \\
\text { tas }\end{array}$ & Target & Aktual & $\begin{array}{c}\text { Efektivit } \\
\text { as }\end{array}$ & Target & Aktual & $\begin{array}{c}\text { Efektivit } \\
\text { as }\end{array}$ \\
\hline $\begin{array}{l}\text { Pengajuan } \\
\text { KUR }\end{array}$ & 251 & 236 & $94,02 \%$ & 751 & 720 & $95,87 \%$ & 495 & 465 & $93,93 \%$ \\
\hline
\end{tabular}

Sumber : Data Olahan

Untuk menilai efektivitas penjaminan kredit maka aspek yang digunakan adalah permohonan yang diajukan dan yang terrealisasi dari tahun 2015-2017. untuk mendapatkan kriteria efektivitas maka perhitungan efektivitas penjaminan kredit Menggunakan rumus berikut :

$$
\text { Efektifitas }=\frac{\text { Ouput aktual }}{\text { Output target }} \times 100 \%
$$

1. Tahun 2015: Efektifitas $=\frac{236}{251} \times 100 \%=94.02 \%$ artinya efektif

2. Tahun 2016: Efektifitas $=\frac{720}{751} \times 100 \%=95.87 \%$ artinya efektif

3. Tahun 2017: Efektifitas $=\frac{465}{495} \times 100 \%=93.93 \%$ artinya efektif

Dari rumus yang digunakan diatas dapat disimpulkan bahwa Penjaminan kredit di Kota Manado Sulawesi Utara sudah mencapai kategori Efektif dimana pada tahun 2015 mencapai 94,02\% selanjutnya dengan jumlah Nasabah terbanyak pada 3 Tahun terakhir dengan persentase mencapai 95,87\% dan yang terakhir pada Tahun 2017 masih bertahan pada kategori Efektif dengan persentase $93.93 \%$.

Berdasarkan hasil penelitian diatas dapat dilihat pada tahun 2015 awal mula Kredit Usaha Rakyat di salurkan oleh pemerintah Nasabah mencapai 3.752 dan terjadi peningkatan lagi pada tahun 2016 mencapai 16.750 Nasabah dan terakhir pada tahun 2017 mencapai 10.344 Nasabah. Maka sejak tahun 2015 pada pertama kali KUR diluncurkan hingga saat ini 2017. Dapat dilihat program Kredit Usaha Rakyat ini sudah berjalan dengan Efektif karena terjadi peningkatan Nasabah sejak Tahun 2015 Hingga Saat ini Tahun 2017 Jaminan Kredit Indonesia sudah menjamin 30.846 Nasabah.

\section{KESIMPULAN DAN SARAN}

\subsection{Kesimpulan}

Penjaminan kredit merupakan salah satu layanan jasa yang diberikan oleh Perusahaan Umum Jaminan Kredit Indonesia (Jamkrindo) untuk memfasilitasi Usaha Mikro Kecil dan Menengah guna mendapatkan kemudahan memperoleh kredit dari Bank atau Lembaga Pembiayaan Keuangan lainnya. Penjaminan Kredit yang dijaminkan oleh Jamkrindo sangat membantu rakyat kecil yang hendak mengajukan kredit namun tidak memiliki agunan. Penelitian ini dilakukan untuk mengukur seberapa efektif Penjaminan yang sudah dijaminkan Perusahaan Penjaminan kepada nasabah yang mengajukan KUR lewat Bank yang telah bekerjasama dengan Pemerintah. 
Berdasarkan hasil penelitian dan pembahasan dari bab sebelumnya, Kredit Usaha Rakyat (KUR) yang di programkan Pemerintah melalui perusahaan penjaminan Jamkrindo (Jaminan Kredit Indonesia) sudah berjalan dengan efektif dilihat dari tahun 2015 awal mula KUR diluncurkan Kriteria Efektivitas mencapai 94,02\% dan pada tahun 2016 Kriteria Efektivitas Penjaminan Kredit angka 95,87\% dan yang terakhir pada tahun 2017 Kriteria Efektivitas Penjaminan Kredit telah mencapai 93,93\%, artinya Penjaminan Kredit Usaha Rakyat melalui perusahaan Penjaminan Jaminan Kredit Indonesia sudah berada pada kategori Efektif dan telah menjaminkan 30.846 Nasabah sejak tahun 2015. Hasil penelitian ini juga menunjukan bahwa perusahaan mengalami peningkatan pendapatan karena setiap tahun minat dari masyarakat untuk memulai suatu usaha meningkat maka IJP (Imbal Jasa Penjaminan) perusahaan semakin bertambah dan tentunya menambah keuntungan bagi perusahaan itu sendiri.

\subsection{Saran}

1. Perum Jamkrindo Kantor Cabang Manado untuk mempertahankan kinerja pelayanan kepada masyarakat juga mempertahankan kinerja perusahaan agar Penjaminan Kredit tetap efektif.

2. Masyarakat harus bertanggung jawab dan menjaga kepercayaan yang telah diberikan oleh Perbankan dan Perum Jamkrindo dalam hal kredit serta penjaminannya.

\section{DAFTAR PUSTAKA}

Aditya, S. 2014. Efektivitas Program Kredit Usaha Rakyat (KUR) Dalam pengembangan usaha mikro di PT.Bank Rakyat Indonesia (BRI) Persero Cabang Diponegoro. Skripsi. Universitas Diponegoro.

Julita, 2013. Analisis Efektivitas Dan Efisiensi Anggaran Pendapatan Belanja Pada Badan Lingkungan Hidup Provinsi Sumatera Utara. Skripsi. Universitas Muhammadiyah Sumatera Utara.

Juniarti, E. 2016. Analisis Peran Kredit Usaha Rakyat (KUR) Terhadap Pengembangan Usaha UMKM Di Kota Bandung. Skripsi. Unpas Bandung.

Kasmir, 2012. Dasar-dasar perbankan. Jakarta: Raja Gradindo Persada (Rajawali Perss).

Kinya, D. 2015. Effect of Loan Terms and Conditions on Loan Volume Granted. IOSR Journal of Business and Management (17): 13-14.

Putu, S. 2015. Pengaruh Aspek Kepribadian Pada Efektivitas Pemberian Kredit. Skripsi. Universitas Udayana.

Sagner, J. 2016. Bank Lending To Corporations: Scenario Analysis as. Journal of Applied Finance \& Banking (3): 147-159.

Samosir, H. 2016. Analisis Efektivitas Pengendalian Intern Pemberian Kredit Pada PT. Bank Sumut Kantor Cabang Sidikalang. Skripsi. Universitas HKBP Nommensen Medan.

Sugiyono, 2011. Metode Penelitian Kuantitatif Kualitatif dan R\&D (cetakan ke-14). Bandung: Alfabeta.

Ulum, \& Ahyul. 2009. Audit Sektor Publik Suatu Pengantar. Jakarta: Bumi Askara.

Wardhani, N. 2010. Pelaksanaan Pemberian Kredit Usaha Rakyat (Kur) Pada Bank Rakyat Indonesia Unit Kuwarasan Cabang Gombong. Skripsi. Universitas Sebelas Maret Surakarta. 